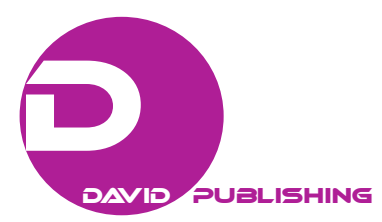

\title{
Effect of Emotional Intelligence on Investment Decision Making With a Moderating Role of Financial Literacy
}

\author{
Fazal Hadi \\ Capital University of Science and Technology, Islamabad, Pakistan
}

\begin{abstract}
This study explores the impact of emotional intelligence on investment decision making with a moderating role of financial literacy. The data are collected by using convenient sampling technique through a 5-point Likert scale questionnaire from a sample of 160 investors from stock exchange and banks. We found a positive and significant relationship between emotional intelligence and investment decision making and the same between financial literacy and investment decision. In addition, when we examined these two relationships under financial literacy, the relationship between emotional intelligence and investment decision making was further strengthened and significantly associated. The results suggest that to make suitable investment decisions, investors should have control on their emotions. Moreover, financial literacy of investors moderates this relationship. Investor's decision making may depend on other factors that need to be explored for in addition to what we have found in our study. The sample size and geographical coverage should increase to consider the importance of this study.
\end{abstract}

Keywords: emotions, emotional intelligence, investment decision, financial literacy

\section{Introduction}

Better management of one's emotion leads one's path towards successful decision making. Emotions play an important role in the liking of things for an individual (Leary, Reilly, \& Brown, 2009). Planning, assessment, and execution of quality decisions for organization, company, and individuals are linked with the intrinsic and extrinsic elements (Hess \& Bacigalupo, 2011). Emotional intelligence is the ability of a person to state his emotions and attach with those he receives from his surroundings and with the association of the people (Ahangar \& Rooshan, 2010). Investors will make better decisions when they identify and understand their emotions, and it will make them minimize the conflicts associated with the decision making process (Hess \& Bacigalupo, 2011).

According to Killian (2012), emotional intelligence is the skill to identify and recognize emotions on self and bring about it to improve well-being and the worth of one's professional and personal relationships. Emotional intelligence, which is like an umbrella consists of three different elements, i.e., assessment and communication of emotions, regulation of emotions, and utilization of emotional idea in thought and acting (Petrides \& Furnham, 2000).

Financial literacy moderates the relationship of emotional intelligence and investment decisions in such a

Fazal Hadi, MS scholar at Capital University of Science and Technology, Islamabad, Pakistan.

Correspondence concerning this article should be addressed to Fazal Hadi, P.O. 19021 Chail Madyan, District Swat, KPK Pakistan. 
way that it strengthens the both link. We have used the moderating role of financial literacy for emotional intelligence and investment decision for the first time which have not been studied in details before.

Investors who have more financial knowledge of financial market will also have the ability to control his own emotions, and consequently he will make effective decision making. Emotions are considered a tool to solve problems in decision making as they influence decisions (de Laar \& de Neubourg, 2006).

There is an influence of feelings on investor decision-making and it is considered an effective decisions making tool (Lucey \& Dowling, 2005). This capability of emotional intelligence not only improves the system of decision making but also the consequence of the decision making. Individuals who are self-aware can make effective decisions than others (Hess \& Bacigalupo, 2011). Similar to other framework, emotional intelligence is also a major determinant of making optimal financial and investment decisions.

According to the thought of different researchers, we can say that emotional intelligence develops the character of a person and equips him with the tools and skills to better cope with the situations, creating a capacity for undertaking improved decision making. The relationship between emotional intelligence and investment decisions has been explored by some researchers. Decision maker, who uses better management of his/her emotions and has sufficient information of financial instruments, will be able to handle the situations and make sound financial decisions than others, while making investment decisions either at individual level or organizational level. However, much more researches have to be conducted to study the impact of emotional intelligence on investment decisions.

\section{Literature Review}

\section{Emotional Intelligence}

Emotional intelligence is the ability to recognize one's own and other people's emotions, to differentiate between different feelings and label them appropriately, and to use emotional information to guide thinking and behavior. Thorndike and Stein (1937) proposed the existence of social intelligence for the first time which they define as the ability of a person to understand and manage people. According to them social intelligence is the process to identify one's own emotions and other people's emotions and internal states and as a result of act in a proper manner. Emotional intelligence leads to effective decision making (Ladd \& Chan, 2004). Social intelligence consists of social skills that are very crucial element, comprising of capabilities such as to involve oneself in social relations, to handle different situations, knowledge of social norms, team management, and individual problem resolving skills (Riggio \& Reichard, 2008). In past, social intelligence was supposed to be a more important determinant than emotional intelligence to measure intelligence of individual. Today emotional intelligence is thought to be a more major factor to determine intellect than social intelligence. The focus of emotional skills is on emotions. Skills of both IQ and EQ are different from each other (Riggio \& Reichard, 2008). The base of the idea of emotional intelligence is the idea of social intelligence (HjYunus \& Hassan, 2012).

Investment decision is the determination of an individual to where and when to spend Capital and how much Capital to be spent in the search of making a profit. Investment decision making changes with the period of time in terms of diversification and trading frequencies. However, an effective decision making strategy is essential for investment decision. Experienced and aged investors prefer high diversification, hold low risk portfolios, trade less frequently and this investment skill becomes worse at an age of 70 (Korniotis \& Kumar, 2010). The reliability of investment decisions is based on effective investment return strategy development 
(Rutkauskas \& Stasytyte, 2008). It is not necessary that agents behave rationally on several aspects of decision making process that is not completely understood so far (Scalliet, Karoui, Jeanblanc, \& Martellini, 2008). Investors need to know the combined distributions that show possible results of their investment decisions since they don't know the final outcome of their investment decisions (Weber, 2005).

\section{Financial Literacy}

Financial literacy is the ability to understand how money operates in the world, how one succeeds to earn or make it, how that person manages it, and how he or she invests it. Investors, who want effective investment decision require financial literacy which is the major skill. Customers who work in a complicated financial environment need financial literacy, which is quickly acknowledged as a key skill (Atkinson \& Messy, 2012). Financial literacy is the tool that a household requires so that they better plan for retirement and accomplish them (Lusardi \& Mitcell, 2006). Financial literacy is the key variable that explains portfolio diversification (Guiso \& Jappelli, 2008). Financial literacy is the capacity to know about basic concepts of finance such as inflation, compounding, and investment returns (Hastings \& Mitchell, 2011). People who have initial financial literacy and who invest in financial literacy have better approach to better investment decisions resulting in high returns (Jappelli \& Padula, 2011).

\section{Emotional Intelligence and Investment Decision}

Salovey and Mayer (1995) were the first who introduced the concept of emotional intelligence. According to them, emotional intelligence is the capability of identifying opinions and feelings of one and others and differentiating between these feelings so as to aid to run thoughts and actions. Their model of emotional intelligence faced a lot of censure. Later, Mayer, Caruso, and Salovey (1999) reported these censure in their paper; there is no proficiency to link emotions with intelligence as intelligence is more controversial area and emotions would be unable to measure the complete range of intelligence. They make a speech that emotional intelligence is a systematic mental phenomenon and this capability is a kind of intelligence. Emotional intelligence shows a discrepancy among people as some people have high while others have low emotional intelligence; some have more knowledge of their feelings while others have not and this familiarity gifts them with ability to control their own feelings and compare to other. There is a connection among emotional intelligence, personality, and clinical psychology (Mayer \& Salovey, 1995). They categorize emotional intelligence into emotional orientation, emotional involvement, and emotional expertise. Later on, Goleman (2010) categorizes them into four more elements such as self-awareness, self-management, social awareness, and relationship management. Self-awareness is the ability to understand the emotions that are disturbing our thoughts and subconscious in mind and lead us to think in some directions (Quinn \& Wilemon, 2009). Self-management is the ability to control one's emotions and prevent one's self from acting on coercion without taking into account thought and emotional reaction (Quinn \& Wilemon, 2009). Social awareness is the ability to have knowledge of people from different experiences or from different cultures (Barling, Slater, \& Kelloway, 2000). Relationship management is the management of other people's emotions.

Different researchers have different opinions about emotional intelligence. People who are good at joining thoughts to their feelings are well knowledgeable about emotional intelligence; they have good understanding of their and others' emotions as well (Mayer \& Geher, 1996). Emotional intelligence is identifying one's own and other's emotions and used to solve problem (Schutte, Malouff, Hall, Haggerty, Cooper, Golden, \& Dornheim, 1998) and has the ability to understand the elements; how they vary, and as a result perceive about 
emotions (Mayer, Caruso, \& Salovey, 2000). EI involves three different components such as assessment and appearance of emotions, regulations of emotions, and practice of emotional information in thinking and acting (Petrides \& Furnham, 2000). The capability to identify emotions is one of the crucial elements of emotional intelligence and it is useful in forecasting the social success (der Zee, Thijs, \& Schakel, 2002). It is a major factor of real life result (Saklofske, Austin, \& Minski, 2003) and success (Alon \& Higgins, 2005). Emotional intelligence has four subdivisions: perceiving emotions, using emotions to enable thought, understanding emotions, and managing emotions (Y.-H. Yao, R.-T. Wang, \& K. Y. Wang, 2009) and also identifies the relationship between feelings, thoughts, and behavior (Ahang \& Rooshan, 2010). The idea of emotional intelligence covers psychology and controlling of multiple features such as emotional perception and understanding of emotions ( $\mathrm{Lu}, \mathrm{Bai}, \&$ Wang, 2011) and enhances the decision making process (Scott-Ladd \& Chan, 2004). Emotional intelligence is an important determinant in decision making process. People who have high EQ and have good management of their emotions could develop the skill to accomplish their goal and understand the outcome of causes that affects the results. Sevdalis, Petrides, and Harvey (2007) reported that decision makers presume their emotions before making a decision and they practice them when they receive the outcome of their decisions, and they recall their memory when they suppose former decisions as good or bad. The path of emotional intelligence goes to progressive results because it raises the confidence level of individuals (Gardner \& Stough, 2002).

Emotions influence decisions making and are considered as a tool to solve problems in decision making (de Laar \& Neubourg, 2006). This capability of emotional intelligence not only improves the system of decision making but also the consequence of the decision making. Individuals who are self-aware can make more effective decisions than other (Hess \& Bacigalupo, 2011). Similar to other frameworks, emotional intelligence is also a major determinant of making optimal financial and investment decisions. As in other frameworks, emotional intelligence is also a good characteristic of investment decision making and is supposed as a major tool in increasing the effectiveness of individual in dealing their crossing point with participants (Quinn \& Wilemon, 2009). From the above discussion we can conclude that individuals who have high emotional intelligence will have more chances to have successful results of their investment decisions than those who have less emotional intelligence.

$\mathrm{Ha}_{1}$. Emotional intelligence is positively related to investment decision making.

\section{Financial Literacy and Investment Decision}

Money is an important component in our social life and a source of finance. To make an effective utilization of money, one can save or invest it in financial market and should have important financial information in order to know the trading of financial product in market (Zvaríková \& Majerová, 2013). Financial literacy is the combination of knowledge, skills, and confidence necessary to make liable financial decisions (Altman, 2012). There is a positive relationship between education level and literacy. There is a strong relationship between the general education and financial literacy (Duca \& Kumar, 2014). Educated people know well the changing aspects of financial market than uneducated people. The need for financial literacy has become significant after the advancement in financial markets (Marcolin \& Abraham, 2006). Social relations with colleagues, friends, and family members have significantly influenced individuals' financial knowledge and decision to actively take part in financial markets. Word-of-mouth communication conveys information effectively due to geographical closeness (Bönte \& Filipiak, 2012). 
The outcomes are different from high and low literacy of financial instruments. According to Rooij, Lusardi, and Alessie (2007), individuals who have low literacy level are less probable to take part in stock market and depend on their relatives for financial information. Lee, Yun, and Haley (2012) found that investors with low financial knowledge were probably giving less attention to advertised mutual funds than those with high financial knowledge. Investors with low financial literacy are likely to have low confidence when interpreting credit terms, and show mix-up over financial concepts. They also pause to involve in activities which could help them to enhance their cognizance of the financial market (Disney \& Gathergood, 2013). The workplace activities and income level leading to better learning trainings have an impact on level of financial literacy of an individual (Al-Tamimi \& Kalli, 2009). Literacy level of households is very weak as they don't know the basic concepts of bonds and stocks, connection between price and interest rates of bonds, and basic concepts of diversification (Rooij, Lusardi, \& Alessie, 2007). They depend on savings as they believe that savings will benefit them in productive investment and will smooth their consumption (Karlan, Ratan, \& Zinman, 2014).

Financial literacy plays an important role in planning and decision making. Generally people who have low literacy and experience lead to poor planning. Literacy level affects the wealth of the holder because it influences the planning processes (Lusardi \& Mitchell, 2007b; Jappelli \& Padula, 2013). Financial literacy is the key determinant which effects the investment decision (Rooij, Lusardi, \& Alessie, 2007; Al-Tamimi \& Kalli, 2009; Rooij \& Lusardi, 2009). Level of income and education influences level of financial literacy. Individuals who work in financial market generally have higher financial literacy level than others and those who have high financial position, hold high educational degrees (Al-Tamimi \& Kalli, 2009). Financial education and financial consequence are linked with financial literacy (Huston, 2010). If individuals have positive attitude to take risky decisions that can be improved by participation in the decision making process and it can also be corrected with a facilitation of quality information to decision makers (Altman, 2012). From the above discussion, we can conclude that financial literacy has a positive relationship with investment decision making.

$\mathrm{Ha}_{2}$. Financial literacy is positively related to investment decision making.

\section{Moderating Role of Financial Literacy Between Emotional Intelligence and Investment Decision}

Financial literacy is the mixture of awareness, attitude, behavior, knowledge, and skill required to make an effective investment decision and as a result accomplish economic wellbeing (Atkinson \& Messy, 2012). Financial decisions are affected by the assistances of information and financial knowledge (Lusardi \& Mitchell, 2007b). When people have high level of financial literacy, then their investment behavior might hang on the dominance of two thinking styles in relation to dual-process theories (Glaser \& Walther, 2013). When the investors are more financially literate, they would participate in short term investments (Akhtar, Rehman, \& Hunjra, 2011).

According to Rooij, Lusardi, and Alessie (2007), investors, who have no financial education, do not know the practical operations of stock market and are not aware of the financial instruments, and have little or no interest in the stock market or depend on the guidance of friends and family after making investment decisions. Many people do not have sufficient information regarding fundamental concepts of economics and finance such as risk diversification, inflation, and interest element, which lead them to acquire little or no required return (Jappelli \& Padula, 2013). As Hastings and Mitchell (2011) report that individuals who have poor knowledge 
of basic economic concepts and abilities necessary to make calculation, will be unable to make extraordinary investment decisions. Financial literacy is strongly linked with the extent of portfolio diversification and there is evidence that under diversification is associated with low financial literacy (Guiso \& Jappelli, 2008). From the above discussion we can conclude that financial literacy moderates the relationship of emotional intelligence and investment decisions. Decision makers who are more financially literate are also more emotionally intelligent and consequently, will make better investment decisions.

$\mathrm{Ha}_{3}$. Financial literacy plays a moderating role between emotional intelligence and investment decision.

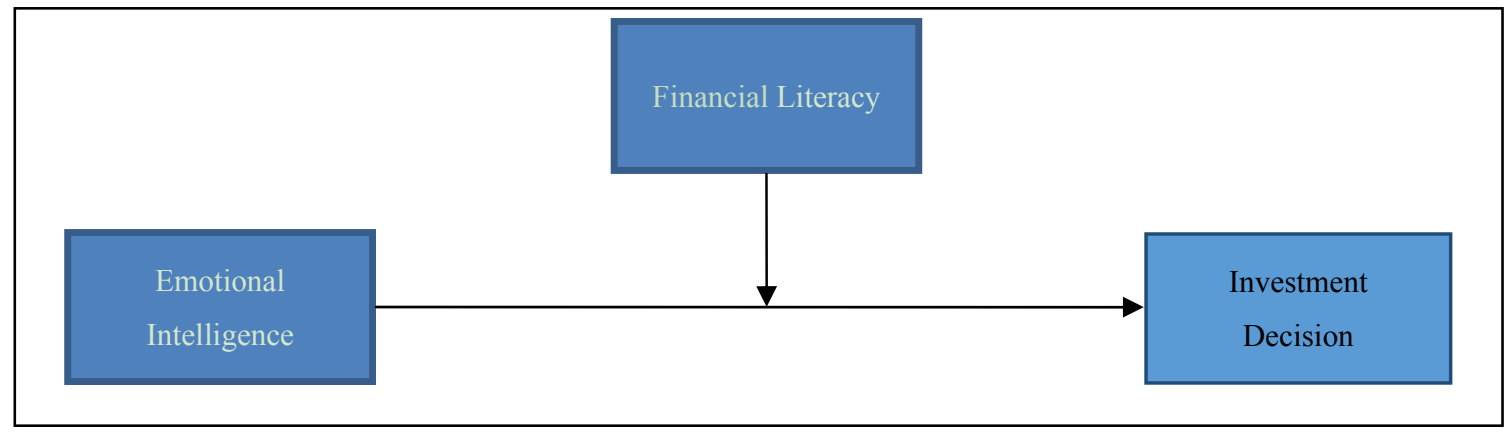

Figure 1. Theoretical framework.

\section{Research Methodology}

\section{Sampling}

The sample consists of investors who had invested in different stock exchange in Pakistan and abroad. Total of 225 questionnaires were distributed in Islamabad Stock Exchange and in different banks and in offices. Out of 225 questionnaires 160 were received back from which 150 usable; hence the response rate was $70 \%$.

The respondents consisted of $94.4 \%$ (151) male and 5.6\% (9) female. The mean age of respondents was between 26-33. Education levels ranged from high school to Ph.D. from which with 5\% of the respondents had a matriculation degree, $7.5 \%$ were intermediate, 36.2\% Bachelors, 46.3\% Masters, 3.8\% MS, and 1.3\% Ph.D. holders. $40 \%$ of investors had experience from $1-5$ years in investment, and other $60 \%$ had experience of more than five years in investment.

\section{Measurement of Variables}

All item scales of the variables were adopted from prior studies where they had been tested for reliability and validity. A 5-point Likert scale having a range from strong disagreement to strong agreement was used. The 14 scale questionnaire to measure the emotional intelligence was adopted from Wong and Law Emotional Intelligence Scale (WLEIS) (Wong \& Law, 2002) with a reliability of 0.865 . A 14 items financial literacy questionnaire was measured using a scale adopted from Annamaria Lusardi (2008), and Lusardi and Mitchell $(2006,2007 a)$ with a reliability of 0.846 . Investor behavior was measured using State Street's approach with a reliability of 0.905 .

\section{Results}

Correlation analysis shows a significance relationship between the independent variable (emotional intelligence) and moderation variable (financial literacy). Table 1 shows that emotional intelligence is positively and significantly correlated to financial literacy $\left(0.979^{* *},{ }^{* *} P<0.001\right)$. Correlation analysis also 
specifies that investor behavior is positively and significantly correlated to financial literacy $\left(0.983^{* *}\right.$, $\left.{ }^{* *} P<0.001\right)$.

Table 1

Correlation Analysis

\begin{tabular}{lllllllll}
\hline & Variable & 1 & 2 & 3 & 4 & 5 & 6 & 7 \\
\hline 1 & Gender & 1 & & & & & & \\
2 & Age & $-0.302^{* *}$ & 1 & & & & & \\
3 & Qualification & $0.208^{* *}$ & 0.100 & 1 & & & \\
4 & Experience & $-0.183^{*}$ & $0.251^{* *}$ & 0.080 & 1 & & \\
5 & Emotional intelligence & 0.048 & -0.080 & 0.080 & -0.069 & 1 & \\
6 & Financial literacy & 0.017 & -0.042 & 0.078 & -0.054 & $0.979^{* *}$ & 1 \\
7 & Investment decision & 0.050 & -0.088 & 0.087 & -0.061 & $0.994^{* *}$ & $0.983^{* *}$ & 1 \\
\hline
\end{tabular}

Note. ${ }^{* *} P<0.001,{ }^{*} P<0.05$.

Table 2

Regression Analysis

\begin{tabular}{|c|c|c|c|}
\hline \multirow{2}{*}{ Predictors } & \multicolumn{3}{|c|}{ Investment decision } \\
\hline & $\mathrm{B}$ & $R^{2}$ & $\Delta R^{2}$ \\
\hline \multicolumn{4}{|l|}{ Step1 } \\
\hline Control variables & & 0.023 & \\
\hline \multicolumn{4}{|l|}{ Step 2} \\
\hline Emotional intelligence & $1.070^{* * *}$ & 0.990 & 0.967 \\
\hline
\end{tabular}

Notes. $\mathrm{N}=160$; control variables: age, gender, qualification, and experience, ${ }^{* *} P<0.001,{ }^{*} P<0.05$.

Table 3

Moderation Regression Analysis

\begin{tabular}{llll}
\hline Predictors & \multicolumn{2}{c}{ Investment decision } \\
\cline { 2 - 4 } & $\mathrm{B}$ & $R^{2}$ & $\Delta R^{2}$ \\
\hline Step 1 & & 0.023 & 0.967 \\
Control variables & $0.281^{* *}$ & 0.990 & 0.003 \\
Step 2 & $-0.161^{*}$ & 0.992 & 0.002 \\
Emotional intelligence & $0.125^{* * *}$ & 0.995 & \\
Financial literacy & Step 3 &
\end{tabular}

Notes. $\mathrm{N}=160$; control variables: gender, age, experience, and qualification; ${ }^{* *} P<0.001,{ }^{*} \mathrm{P}<0.05$.

The regression and moderation regression analysis were used to study the moderating role of financial literacy of investors between emotional intelligence and investment decision making. The results show that after controlling the control variables and moderation, there still exists a significant relationship between emotional intelligence and investment decision $(\beta=0.281, P=0.002)$. This shows that the relationship of dependent and independent variables does not need any moderating variable.

\section{Conclusion and Discussion}

The main aim of our research paper was to study the significant effect of emotional intelligence on investment decision making with a moderating role of financial literacy. To support our claim, we developed hypothesis on the basis of previous researches and tested those hypotheses by using different measurement tools. 
Simplifying our results, all of our hypotheses, $\mathrm{Ha}_{1}, \mathrm{Ha}_{2}$, and $\mathrm{Ha}_{3}$, have been accepted. The direct link between emotional intelligence and investment decision making and the direct link between financial literacy and investment decision making have been accepted. In addition, when we examined these two relationships under financial literacy, the relationship between emotional intelligence and investment decision making was further strengthened and significantly associated.

Studies propose a significant relationship between emotional intelligence and investment decision making of an investor. Investors who have the ability to control their emotions are better decision makers than those who are less emotionally intelligent. Similar to previous researches which were conducted to examine the relationship between emotional intelligence and investment decision making, our results also demonstrate a significant relationship between these two variables.

Literature also recommends that investors who have more knowledge of financial instruments and stock market behavior can make better investment decisions as compared to those who are financially illiterate by keeping in mind the total factors that could influence their decision making ability. Here we also establish the same significant and positive relationship between financial literacy of investors and investment decision making.

Moreover, when we studied the relationship between emotional intelligence and investment decision making of individuals under the influence of financial literacy in the same situations, we found even more significant and positive relationship between these two variables. Financial literacy of investors did play a significant moderated role between the associations of emotional intelligence and investment decision making. One of the major reasons of the acceptance of this hypothesis is that the financial literacy of investor enhances the ability of an individual to control and manage his emotions, and consequently lead him towards successful investment decision making. However financial literacy could only increase the intensity of emotional intelligence and investment behavior, but could not totally change the investment attitude of investors and it is not necessary that financial literacy completely changes the investment behavior of an investor. An individual may not be totally financially literate but even though he could involve in investment decision making as we have identified in our study in the context of Pakistan.

\section{Limitations}

The sample size chosen for the study was quite small as we conducted the study in Islamabad and Rawalpindi area only. Still, the sample size and geographical coverage should have to be larger to consider the importance of this study.

\section{Future Extension of the Study}

Investors' decision making may depend on other factors that need to be searched for in addition to what we have found in our study. Our research only focused on emotional intelligence and financial literacy as factors affecting investment decision making.

However, the areas are suggested for further extension of the study, and investment strategy will be favorable in Pakistan as in Pakistan the culture is different and people with low financial literacy are mostly involved in investment decision making. Also there may be the role of gender in this process as male are mostly investors. 


\section{References}

Ahangar, R. G., \& Rooshan, A. A. (2010). Emotional intelligence as determinant/predictor of work performance among executives. 2010 International Conference on Financial Theory and Engineering (ICFTE), 147-150.

Akhtar, M. N., Hunjra, A. I., \& Rehman, K. U. (2011). Determinants of short term investment decision making. Actual Problems of Economiics, 11, 356-363.

Alon, I., \& Higgins, J. M. (2005). Global leadership success through emotional and cultural intelligences. Business Horizons, 48(6), 501-512.

Al-Tamimi, H. A. H., \& Kalli, A1. A. B. (2009). Financial literacy and investment decisions of UAE investors. The Journal of Risk Finance, 10(5), 500-516.

Altman, M. (2012). Implications of behavioural economics for financial literacy and public policy. The Journal of Socio-Economics, 41(5), 677-690.

Atkinson, A., \& Messy, F. A. (2012). Measuring financial literacy: Results of the OECD/International Network on Financial Education (INFE) pilot study. OECD Working Papers on Finance, Insurance and Private Pensions, 15. OECD Publishing.

Barling, J., Slater, F., \& Kelloway, E. K. (2000). Transformational leadership and emotional intelligence: An exploratory study. Leadership \& Organization Development Journal, 21(3), 157-161.

Blanchet-Scalliet, C., El Karoui, N., Jeanblanc, M., \& Martellini, L. (2008). Optimal investment decisions when time-horizon is uncertain. Journal of Mathematical Economics, 44(11), 1100-1113.

Bönte, W., \& Filipiak, U. (2012). Financial literacy, information flows, and caste affiliation: Empirical evidence from India. Journal of Banking \& Finance, 36(12), 3399-3414.

de Laar, M. V., \& de Neubourg, C. (2006). Emotions and foreign direct investment: A theoretical and empirical exploration. Management International Review, 46(2), 207-233.

der Zee, K. V., Thijs, M., \& Schakel, L. (2002). The relationship of emotional intelligence with academic intelligence and the Big Five. European Journal of Personality, 16(2), 103-112.

Disney, R., \& Gathergood, J. (2013). Financial literacy and consumer credit portfolios. Journal of Banking \& Finance, 37(7), 2246-2254.

Dowling, M. M., \& Lucey, B. M. (2005). The role of feelings in investor decision-making. Journal of Economic Surveys, 19(2), 211-237.

Duca, J. V., \& Kumar, A. (2014). Financial literacy and mortgage equity withdrawals. Journal of Urban Economics, 80, 62-75.

Gardner, L., \& Stough, C. (2002). Examining the relationship between leadership and emotional intelligence in senior level managers. Leadership \& Organization Development Journal, 23(2), 68-78.

Guiso, L., \& Jappelli, T. (2008). Financial literacy and portfolio diversification.

Goleman, D. (2010). Inteligencia emocional (Spanish Edition). Spanish: Editorial Kairos.

Hastings, J. S., \& Mitchell, O. S. (2011). How financial literacy and impatience shape retirement wealth and investment behaviors. NBER Working Paper, 16740. National Bureau of Economic Research.

Hess, J. D., \& Bacigalupo, A. C. (2011). Enhancing decisions and decision-making processes through the application of emotional intelligence skills. Management Decision, 49(5), 710-721.

HjYunus, N., \& Hassan, C. N. (2012). Notice of retraction: The importance of emotional intelligence and soft skills in the workplace. International Conference on Innovation Management and Technology Research (ICIMTR), 12-16.

Huston, S. J. (2010). Measuring financial literacy. Journal of Consumer Affairs, 44(2), 296-316.

Jappelli, T., \& Padula, M. (2011). Investment in financial literacy and saving decisions. Journal of Banking \& Finance, 37(8), 2779-2792.

Karlan, D., Ratan, A. L., \& Zinman, J. (2014). Savings by and for the poor: A research review and agenda. Review of Income and Wealth, 60(1), 36-78.

Killian, K. D. (2012). Development and validation of the emotional self awareness questionnaire: A measure of emotional intelligence. Journal of Marital and Family Therapy, 38(3), 502-514.

Korniotis, G. M., \& Kumar, A. (2010). Cognitive abilities and financial decisions. Behavioral Finance, 559-576.

Lu, K.-Y., Bai, Y.-G., \& Wang, Y.-J. (2011). Study on the relationship between emotional intelligence and employee performance. 2011 International Conference on Management and Service Science (MASS), 1-4.

Leary, M. M., Reilly, M. D., \& Brown, F. W. (2009). A study of personality preferences and emotional intelligence. Leadership \& Organization Development Journal, 30(5), 421-434. 
Lee, T. D., Yun, T. W., \& Haley, E. (2012). The interplay between advertising disclosures and financial knowledge in mutual fund investment decisions. Journal of Consumer Affairs, 46(2), 260-287.

Lusardi, A., \& Mitchelli, O. (2006). Financial literacy and retirement preparedness: Evidence and implications for financial education. Business Economics, 42(1), 35-44.

Lusardi, A. (2008). Financial literacy: An essential tool for informed consumer choice? Working Paper. National Bureau of Economic Research.

Lusardi, A., \& Mitchell, O. S. (2007a). Financial literacy and planning: Implications for retirement wellbeing. Working Paper. Pension Research Council, The Wharton School.

Lusardi, A., \& Mitchell, O. S. (2007b). Baby boomer retirement security: The roles of planning, financial literacy, and housing wealth. Journal of Monetary Economics, 54(1), 205-224.

Lusardi, A., Van Rooij, M., \& Alessie, R. (2007). Financial literacy and stock market participation. NBER Working Paper, 13565(2007), 162.

Lusardi, A., \& van Rooij, M. (2009). Financial literacy: Evidence and implications for consumer education. Netspar Panel Paper, 16.

Marcolin, S., \& Abraham, A. (2006). Financial literacy research: Current literature and future opportunities. In P. Basu, G. O'Neill, and A. Travaglione (Eds.), Proceedings of the 3rd International Conference on Contemporary.

Mayer, J. D., \& Geher, G. (1996). Emotional intelligence and the identification of emotion. Intelligence, 22(2), 89-113.

Mayer, J. D., \& Salovey, P. (1995). Emotional intelligence and the construction and regulation of feelings. Applied and Preventive Psychology, 4(3), 197-208.

Mayer, J. D., Caruso, D. R., \& Salovey, P. (1999). Emotional intelligence meets traditional standards for an intelligence. Intelligence, 27(4), 267-298.

Petrides, K. V., \& Furnham, A. (2000). On the dimensional structure of emotional intelligence. Personality and Individual Differences, 29(2), 313-320.

Quinn, J. F., \& Wilemon, D. (2009). Emotional intelligence as a facilitator of project leader effectiveness. 2009 Portland International Conference on Management of Engineering \& Technology (PICMET 2009), 1267-1275. IEEE.

Riggio, R. E., \& Reichard, R. J. (2008). The emotional and social intelligences of effective leadership: An emotional and social skill approach. Journal of Managerial Psychology, 23(2), 169-185.

Rutkauskas, A. V., \& Stasytyte, V. (2008). stratification of stock profitabilities-The framework for investors' possibilities research in the market. Practice, 5(8), 9.

Saklofske, D. H., Austin, E. J., \& Minski, P. S. (2003). Factor structure and validity of a trait emotional intelligence measure. Personality and Individual Differences, 34(4), 707-721.

Schutte, N. S., Malouff, J. M., Hall, L. E., Haggerty, D. J., Cooper, J. T., Golden, C. J., \& Dornheim, L. (1998). Development and validation of a measure of emotional intelligence. Personality and Individual Differences, 25(2), 167-177.

Scott-Ladd, B., \& Chan, C. A. (2004). Emotional intelligence and participation in decision making: Strategies for promoting organizational learning and change. Strategic Change, 13(2), 95-105.

Sevdalis, N., Petrides, K. V., \& Harvey, N. (2007). Trait emotional intelligence and decision-related emotions. Personality and Individual Differences, 42(7), 1347-1358.

Thorndike, R. L., \& Stein, S. (1937). An evaluation of the attempts to measure social intelligence. Psychological Bulletin, 34(5), 275.

Van Rooij, M., Lusardi, A., \& Alessie, R. (2011). Financial literacy and stock market participation. Journal of Financial Economics, 101(2), 449-472.

Weber, K. (2005). A toolkit for analyzing corporate cultural toolkits. Poetics, 33(3), 227-252.

Wong, C. S., \& Law, K. S. (2002). The effects of leader and follower emotional intelligence onperformance and attitude: An exploratory study. Leadership Quarterly, 13, 243-274.

Yao, Y.-H., Wang, R.-T., \& Wang, K. Y. (2009). The influence of emotional intelligence on job performance: Moderating effects of leadership. 2009 International Conference on Management Science and Engineering (ICMSE 2009).

Zvaríková, K., \& Majerová, J. (2014). Financial Literacy in the Slovak Republic. Procedia-Social and Behavioral Sciences, 110, 1106-1115. 